\title{
Sylvia Pankhurst and the international auxiliary language
}

\begin{abstract}
Abstrakt (Sylvia Pankhurst i międzynarodowy język pomocniczy). Sylvia Pankhurst była pionierską postacią socjalistycznego feminizmu, który opowiadał się za powszechnym prawem wyborczym i przeciw wojnie. Mniej znane jest jej zaangażowanie w ruch na rzecz międzynarodowego języka pomocniczego. W 1927 roku Pankhurst opublikowała broszurę Delphos. Przyszłość języka międzynarodowego, w którym opisała rosnące zapotrzebowanie na światowy język pomocniczy i jej wsparcie dla języka Interlingua (Latino sine flexione). Osadzone w kontekście biograficznym studium Delphos pokazuje modernistyczne, kosmopolityczne i demokratyczne powołanie ruchu na rzecz międzynarodowego języka pomocniczego na początku XX wieku. Poglądy Pankhurst na temat motywacji i zasad przyszłego interjęzyka były szeroko rozpowszechnione przez międzynarodową społeczność na rzecz języka pomocniczego. Artykuł prezentuje jej wsparcie dla języka Interlingua jako przykład humanizmu naukowego, który zdominował początki interlingwistyki oraz odnosi jej aktywizm językowy do jej socjalistycznych i pacyfistycznych poglądów.
\end{abstract}

\begin{abstract}
Sylvia Pankhurst was a pioneering figure of socialist feminism who advocated for universal suffrage and against war. Less well-known is her involvement in the movement for an international auxiliary language. In 1927, Pankhurst published a booklet, Delphos. The Future of International Language, where she described the growing need for a world auxiliary language and her support for Interlingua (Latino sine flexione). A biographically informed study of Delphos shows the modernist, cosmopolitan and democratic vocation of the international auxiliary language movement in the early $20^{\text {th }}$ century. Pankhurst's views on the motivation and principles of an interlanguage-to-come were widely shared by the international auxiliary language community. We present her support for Interlingua as an example of the scientific humanism that dominated the beginnings of interlinguistics, and relate her language activism to her socialist and pacifist stands.
\end{abstract}

Sylvia Pankhurst was a notable women's rights activist, socialist and anti-fascist. Though her interest in the question of an international auxiliary language was marginal, its study offers an interesting perspective on the relationships between pacifism and science in interlinguistics during the first half of the $20^{\text {th }}$ century. Pankhurst supported the adoption of an international auxiliary language in the name of world peace. In her 
pamphlet Delphos, dedicated to the question of a world auxiliary language, she presents the creation of an interlanguage as an example of scientific progress in the lines of ground-breaking achievements in the fields of telecommunication and transportation. More specifically, she praises Giuseppe Peano's Interlingua for its scientific rigor. This essay argues that the assumption of a dependency between scientific progress and world peace was commonplace in the movement for an international auxiliary language. Given Pankhurst's lifelong political activism, Delphos is a key text in understanding the political aspirations of the international auxiliary language movement. Pankhurst's case is particularly significant due to her fame as a political activist who expressed her support for an interlanguage in terms of world peace and social equality and, not the least, by her reference to scientific methods. In the light of her common views with interlinguists such as Zamenhof, Couturat, Ogden and Hogben, the international auxiliary language movement appears as a modernist and cosmopolitist project emerging as resistance to the global rise in nationalistic tendencies.

In conformity with general trends in the interlinguistics of her time, Pankhurst argued in favour of an a posteriori interlanguage over a priori alternatives, maximal internationality within the limits of Indo-European languages, and the use of the Latin alphabet (for Pankhurst, the accented letters are one of the main defects of Esperanto). She insisted that the lexicon originate from the same language family, to avoid confusion (for example, in a Teutonic-Latin hybrid, "alt" could be interpreted to mean either old or high). An etymological orthography was to be preferred over simplified spelling, to maximize semantic clarity through etymological transparency ${ }^{1}$. Following Peano and before Hogben, Pankhurst insisted on the adoption of an analytic grammar, which would eliminate conjugation and declension by the use of separate particles in conjunction with fixed words, for easier recognisability: "In accord with modern tendencies, the Interlanguage will be logical and analytical, and will contain no more grammar than is required to elucidate the meaning. Every word will be found in the dictionary." (Pankhurst 1927: 52) In the name of maximal internationality, inter-European words should be used in their Latin forms, and the typical Indo-European word order (SVO) should be conserved. Conforming to the evolution of natural languages ${ }^{2}$, Pankhurst prescribes a language construction methodology based on systematizing and simplifying existing language forms. She argues that the evolution of Chinese, Sanskrit and English towards simpler grammatical forms (loss of declensions, genders etc.) shows the way that a world auxiliary language should take in order to succeed in the modern world. Articles were to be eliminated, as was the grammatical gender of inanimate objects. Simplicity requires also the elimination of the redundant concordance between verb and subject. For the same reason, no agreement should be required between an adjective and its noun (in contrast to Esperanto and similar to Ido). In the following, we explain how

1 "Spelling Reform, in reducing a minor obstacle, enhances the difficulty of understanding the meaning of the word, which is of more essential importance." (Pankhurst 1927: 51)

2 Before Pankhurst, Couturat 1911 and Jespersen 1922 made use of extensive data from historical and comparative linguistics for establishing empirical principles for language planning, in an effort to increase the efficiency and the credibility of the international auxiliary language. 
this concern for scientific viability interacts with political motivations in the international auxiliary language movement, through a study of Pankhurst's activism, connections, and concrete positions on matters concerning global communication.

\section{Pankhurst's anti-war activism}

Sylvia Pankhurst (1882-1960) is most famous for her leadership in the movement for women's electoral rights. From 1903, she was active in the Women's Social and Political Union (WSPU) with her mother Emmeline and her sister Christabel. But the war caused a division in the union: in contrast to Sylvia's resolute pacifism and calls to resist the war effort, the majority preferred to side with the government ${ }^{3}$. As a result of this internal conflict, Christabel expelled Sylvia from the WSPU in 1913. Subsequently Sylvia founded the East London Federation of the Suffragettes (ELFS), and started to publish The Women's Dreadnought (later The Workers' Dreadnought). This division in the suffragist movement was actually part of a more widescale division in the socialist movement. Before the war, there was a general consensus on Pankhurst's pacifism among socialists and feminists. The Second International called the workers to boycott a possible upcoming war. However, many, including Sylvia's mother and sister, broke with their earlier pacifist stand to give support to the government. WSPU suspended its activity during the war, and changed the name of its periodical from The Suffragette to Britannia. In contrast, Sylvia Pankhurst's political thought radicalized during the First World War. She not only maintained her opposition to the war, but she heavily campaigned against it, opposing military conscription for men and industrial conscription for women. In 1916, ELFS was renamed the Women's Suffrage Federation and, in the following year, the Workers' Socialist Federation. It is stated to have been "the most active anti-war political group in London" (Weller 1987), and had the biologist and interlinguist Lancelot Hogben (author of Interglossa) on its national committee. In her later life, Pankhurst also advocated for Indian nationalism and for Ethiopian independence (for the latter she and her son Richard Pankhurst are still remembered in Ethiopia).

Pankhurst's anti-war activism is hardly exceptional in the history of the early interlinguistics. Zamenhof was probably the most vocal pacifist among the leaders of the international auxiliary language movement. A considerably sized Esperanto community after Zamenhof continued this, led by Lanti's anationalism and institutionalized through Sennacia Associo Tutmonda (World Anational Association). Conscientious objectors learned Esperanto in Britain, and Pankhurst herself published articles about Esperanto in the Workers' Dreadnought. Indeed, throughout his life, Zamenhof stated that he devised a neutral language mainly for strengthening international friendship and understanding

3 See Winslow 1992 for a detailed presentation of Pankhurst's political activism during the First World War. 
among peoples (which, he expected, would end interethnic conflicts devastating his region, in the long run). In a 1915 article, Peano makes a similar connection between linguistic diversity and war. He calls patriotism "a collective pride that induces us to judge other people inferior", an opinion he considers "erroneous, dangerous and damaging" (Kennedy 1980: 147). Likewise, Charles K. Ogden built his international language project upon the necessity of a common language for humanity, and considered such a language essential for peace and mutual understanding ${ }^{4}$. Ogden, who invented Basic English to serve as a lingua franca, was known for refusing to submit to the ubiquitous anti-German propaganda. His writings against militarism and his publication of German translations in The Cambridge Magazine during the wartime even cost him a mob attack in the journal's premises (Gordon 1990: 18). Another interlinguist, the French logician Louis Couturat (who created Ido as a reformed Esperanto) expressed his anti-patriotism clearly, in his publications (Couturat 1899) as well as in his intimate correspondence with the philosopher and mathematician Bertrand Russell (Russell 2001). Back then, Russell curiously took side with the British Empire and regretted its military loss in South Africa (for which he was accused of jingoism and bigotry by Couturat), but later he played a very active role in the peace movement, and this, throughout his life: he published anti-war pamphlets and encouraged consciousness objection during the First World War; later he organized a movement for nuclear disarmament, and the famous "Russell tribunal" (with Jean-Paul Sartre) to expose war crimes, especially in Vietnam. While imprisoned in 1916, Russell received warm support from Hogben, who had also been arrested for conscientious objection two years prior. The international auxiliary language movement in the first half of the $20^{\text {th }}$ century was the work of this anti-war network, where Pankhurst holds an exceptional place as a relentless organiser.

\section{Pacifism and cosmopolitanism in the international auxiliary language movement}

Pankhurst wrote that the great war was the main reason for the growing interest in an interlanguage - an idea that, according to her, appeared as a pacifist reaction to political conflicts: "Of the influences urging towards Interlanguage, stronger than all is the desire for world-friendship long latent amongst the kindlier and wiser people of all nations, and now quickened to an ardent flame by the agonies of the Worldwar." (Pankhurst 1927: 7) She credited the League of Nations as an establishment for international peace. Already in 1915 Peano anticipated the League and, in the following year, expressed his hope for the creation of a "United States of the World", a confederation to ensure the world peace by unifying the governments and the ar-

4 "The so-called national barriers of today are ultimately language barriers. The absence of a common medium of communication is the chief obstacle to international understanding, and therefore the chief underlying cause of War." (Ogden 1931: 229) 
med forces 5 . Though Pankhurst advocated for an interlanguage for economic reasons affecting the League (manpower and costs related to translations), among others, she affirmed that the search for an interlanguage came ultimately from a desire for peace, more than practical necessities of trade and institutional communication. Despite her reservations about the Esperanto vocabulary, orthography and grammar, she praised the Esperanto movement precisely for its strong commitment to the cause of peace: "For the ideal of a world medium of understanding and utility, of pacification and fraternity, the work of the Esperantists has been unrivalled. It is a great monument of devotion and ability." (Pankhurst 1927: 84) This view was confirmed by Zamenhof's own assertions on the vocation of Esperanto. In Aspirations, Zamenhof insists on the function of Esperanto primarily as a medium for world peace, despite the appeal of its practical advantages in daily communication for many users who are not invested in the cause of establishing a human brotherhood, or might just want to use Esperanto as a practical medium for international trade and travel (Zamenhof 1906).

Pankhurst's pacifism came with a scientific humanism found in other interlinguists and shared by the left-wing movements of her time. According to this modernist worldview enthusiastically adopted by the international auxiliary language community, globalisation is progress, and technological advances go hand in hand with the establishment of a socialist world order. Delphos opens with Pankhurst deploring humanity's ongoing communication problem, contrasted with the unification it achieved on other areas due to advances in technology:

\begin{abstract}
Having failed to achieve a general means of communication, mankind, in the realm of language, has permitted itself to rest internationally upon the level of the dumb animals."... "Yet in other provinces mankind is knitting the globe to a remarkable unity. The interchange of materials between distant countries has led to an interdependence of peoples undreamt of in earlier times. World activities and needs are, and will be, ever more and more co-ordinated. (Sanitation, food, fuel, communications, transport, and education must be regarded from world standpoints). (Pankhurst 1927: 5)
\end{abstract}

Prior to Pankhurst, Couturat brought up in similar terms the necessity to have a neutral international language in the modern world in order to keep up with technological globalisation ${ }^{6}$. For interlinguists, as novel means of transportation and telecommunication gradually became an ordinary part of the daily life for the masses, the world would become increasingly unified and, as a result, linguistic barriers would feel more anachronistic than before. They considered this world unification achieved through new technologies as welcome progress, for it would change the lives of the masses for the

5 "Let us hope that this war will instruct the public on the origins of the present evils, and of the necessity of a confederation of states throughout the world, which will permit the suppression of every army, and the transformation of the instruments of war into the tools of work." (quoted in Kennedy 1980: 147)

“À quoi nous sert de pouvoir voyager, écrire, converser d'un bout du monde à l'autre si nous ne nous "entendons" pas? Nous sommes dans la situation tristement ridicule de sourd-muets à qui l'on offrirait un téléphone?" (Couturat 1906: 4) 
better. In this global context, an interlanguage would emerge both as a natural solution to the growing needs of the modern world, and as a symbol of the progress yet-to-come. Activists often stressed the historical relevance of the interlanguage project, notably to overcome the public prejudice regarding its feasibility.

Pankhurst foresaw a future of material abundance and the consequent dissolution of conflicts, where an interlanguage would be even more relevant as a result of the accelerated globalisation. With instant transmission of news without the need for typesetting and copy-editing, frontiers would become obsolete. Additionally, the global increase in welfare would result in increased leisure time, with more people becoming active in science and the arts. Pankhurst anticipated that, in the future, news and scientific communications would be transmitted in an interlanguage, and the place of natural languages in the press would be restricted to literature. Ultimately, the global unity provided by technological advances in telecommunications and transportation was expected to result in the ending of social stratification and national divisions. This connection was precisely what gave the international auxiliary language movement its resolutely modernist, and spontaneously progressive character. An interlanguage was therefore considered as much a signal of scientific as social progress:

The Interlanguage will play its part in the making of the future, in which the peoples of the world shall be one people: a people cultured and kind, and civilized beyond to-day's conception, speaking a common language, bound by common interests, when the wars of class and of nations shall be no more. (Pankhurst 1927: 94-95)

\section{A democratic language for the popularisation of science}

Of all international auxiliary languages, Peano's Interlingua (formerly Latino sine flexione, first published in 1903) was the one that Pankhurst held at highest esteem. Peano was an arithmetician known for his ground-breaking contribution to mathematical symbolism. He worked on a symbolic language that would make the use of natural languages unnecessary for expressing any arithmetic proposition. This led to the publication of Formulario Matematico in 1895. Formulario was inspired by Leibniz' reflections on the universal language. Like Couturat (a Leibniz expert who popularized Leibniz' ideas on the universal characteristics in 1901), Peano did not limit his interest for a rationally constructed symbolism to the field of mathematics. Following the principles expressed by Leibniz, Peano worked on a modernized Latin, to serve as an international auxiliary language. In Pankhurst's words, Interlingua is "a logical etymological attempt to create the poor man's simplified Latin, which will open to him the nomenclature of the sciences, and will enable him to understand the prescription of his doctor and the legal phrases contained in the lawyer's presentment of his case." (Pankhurst 1927: 85) Since Latin is the main source of scientific terminology, a modernized Latin made accessible would help the popularisation of science. 
For a modernist such as Pankhurst, who was convinced that the spread of scientific knowledge would bring prosperity and social equality ${ }^{7}$, Interlingua's potential role in making science accessible to the common man had an enormous appeal: "To give to everybody's children, all over the world, a language so much like Latin that whoever knows it can read Latin with little study would tremendously accelerate the spread of learning and the breaking down of social barrier." (Pankhurst 1927: 50)

Hogben's later contribution to interlinguistics with Interglossa reflects the same concern for popularising science. Hogben authored The Vocabulary of Science, a compilation of the Greek terms found in today's scientific terminology. He is mostly known to the lay public for his best-sellers in popular science, Science for the Citizen (1938) and Mathematics for the Million (1967). But unlike Peano with Latin, Hogben chose to use Greek roots as the basis of the vocabulary of Interglossa. He defended this choice by the greater recognisability of words originating in Greek, while Latin equivalents might be relatively obscure and limited to specialists (compare the widely understood micro with its lesser-known Latin equivalent parvus). Hogben saw a new pedagogic opportunity in the growing use of scientific terms in everyday language. For Hogben, a Greek-based vocabulary had the double advantage of introducing everyone to the language of science, while making the interlanguage easy to learn thanks to available associations with words used in everyday life ${ }^{8}$. Interglossa was clearly aimed at improving technological awareness by increasing scientific literacy among the lay public. For Hogben, this was a sine qua non condition of long term peace. Furthermore, Hogben made it clear that the practical possibility of an international auxiliary language is conditioned ultimately by the establishment of a science- and community based social order'.

Ideals of world peace and the scientific method were intertwined in the international auxiliary language movement. For interlinguists, alongside benefits to global welfare, scientific activity was an admirable example of human cooperation beyond national borders: "Scientists have such vital need of co-operation that they will gladly clothe their thoughts in the language that will be common to their international fraternity, just

7 Making knowledge accessible is stated by Pankhurst as a desirable outcome for the adoption of an interlanguage: "Within the frontiers, learning spreads from class to class, ever more widely diffused amongst the people. This is a genuine index of progress, and indicates the possibility of establishing an interlanguage which will spread with the growth of education, and assist in promoting that growth." (Pankhurst 1927: 10)

8 "Since the word-material of Interglossa is based on roots internationally current in science, every vocable can form the basis of association with familiar words or with new and interesting information about the world we live in. The process of learning the vocabulary can therefore have the excitement of the chase." (Hogben 1943: 28)

9 "It is not likely that any considerable group of speech-communities will adopt an interlingua unless the forces working for international co-operation are stronger than those which are also working to perpetuate militarism and racialism. To put forward a plan of this sort therefore presupposes confidence in the possibility of a more enlightened world in which the disposition to spread scientific knowledge as a basis of social prosperity and a high standard of communal health prevails. (Hogben 1947: 28)" 
as they did of old in Latin." (Pankhurst 1927: 93) On a more practical note, Pankhurst mentioned the need for translation in international congresses to make a case in favour of the international auxiliary language. These observations reflected a growing internationalisation of governmental and scientific organisations at the beginning of the 20th century, to become the basis of an emerging cosmopolitan (somewhat "anational") ethos expected to spread from the limited circle of scientists to the general public. The movement for an international auxiliary language was indeed endorsed by many scientists who insisted on the benefits of a unified language for a more efficient scientific cooperation. For example, Leopold Pfaundler (Austrian physicist and chemist, 1839-1920), Richard Lorenz (Austrian chemist, 1863-1929) and Wilhelm Ostwald (German chemist, 1909 Nobel prize, 1853-1932) contributed to a volume entitled International Language and Science, alongside Otto Jespersen and Louis Couturat (Couturat et al. 1910).

\section{Interlingua vs. other international auxiliary languages}

For Pankhurst, more than facilitating the teaching of science, Peano's Interlingua had the merit of being constructed using scientific methods. Pankhurst herself was a member of the Academia pro Interlingua. Peano reviewed Delphos in the journal of Academia pro Interlingua, and the Academy mentioned it in 1931 among books on international language, alongside Couturat \& Léau's (1903) and Guérard's (1922). The Academy presented Interlingua as "a modernized international Latin without inflections." (Academia pro Interlingua 1931: 8) Pankhurst did as well: in Delphos, after reviewing the international auxiliary languages up to her day, she sides with Interlingua for using scientific principles of construction. For instance, she criticizes Esperanto for its arbitrary selection of words, despite Zamenhof's general concern for internationality: "Father Schleyer chose English as the main source for his stems. Dr Zamenhof aimed at a wider internationality; but he did not submit the words to the test of tracing them through the various European languages to discover which were in widest usage; nor does he appear to have followed any other consistent method of selection." (Pankhurst 1927: 61) Pankhurst contrasts this shortcoming with Peano's method. In Vocabulario Commune (1909), Peano compiled Latin words found in European languages. According to Pankhurst, this extensive comparative method brought professionalism and scientific rigor to interlinguistics lacking in the works of Schleyer and Zamenhof: "Interlingua marked a new stage in the interlanguage movement, because it was the first artificial language to be constructed, not according to individual choice but upon definite scientific principles." (Pankhurst 1927: 40-41) That is indeed the main argument of the Academy concerning the superiority of Interlingua over other interlanguages developed to its day ${ }^{10}$.

10 "Prof. Peano has given much time to the study of the subject of international language systems and it is he who has laid in large measure a permanent scientific foundation for many of 
The limitation of the aimed universality to the European area is worth noting, and this, was typical of the entire international auxiliary language movement. Pankhurst's concept of interlanguage incorporated the same problematic neutrality as Volapük, Esperanto (and its derivatives), Basic English, Interlingua and Interglossa. Despite accepting the principle of maximum internationality in the choice of vocabulary, Pankhurst leaves this universality inside European borders, on the grounds that modern science emerged in the Western Europe: "The vocabulary of modern Europe will be chosen as the basis of the interlanguage; because that vocabulary has been created in the development of modern science and modern thought." (Pankhurst 1927: 48) She further elaborates this choice by the "greater interest" it presents for the speakers of other languages in familiarizing themselves with European languages ${ }^{11}$.

This concern for using scientific principles was also at the heart of Couturat's attempt to reform Esperanto, which would become the basis of Ido. Moreover, Couturat set up the Délégation pour l'Adoption de la Langue Auxiliaire Internationale as an institution of independent experts on language (Couturat 1906). In its communications, the Delegation stressed the need for professionalism in interlinguistics, and stated that the final decision about the world auxiliary language to adopt should ultimately be left to an expert board. We find a similar argument in Delphos, where Pankhurst suggests that the making of an interlanguage should be free from government interference: "Its discovery and perfection must be mainly the work of philologists, working, not as propagandists and politicians, but as scientists and students." (Pankhurst 1927: 86) Delphos comes with an elaborate idea of a proper institutional structure for working on a future world language, along the lines of the expertise model advanced earlier by Couturat ${ }^{12}$.

To conclude, Pankhurst's biography, connections and views on interlanguage reveal that interlinguistics in the first half of the $20^{\text {th }}$ century was a modernist project grounded in progressive politics. It combined pacifism and cosmopolitism with a very strong emphasis on science as a force of prime importance for global social progress.

those systems by the publication of his Vocabulario Commune showing the occurrence of the same root words in all the principal western languages". (Academia pro Interlingua 1931: 7)

11 "East will gain more than West by this inevitable decision. An immensely larger number of Eastern people learn the languages of Europe than vice versa. An auxiliary language will be of far greater use to the Chinese if it introduce them to the vehicle of Western science, than if allied to their own tongue. Ultimately the value of the Interlanguage must be measured by its gifts, not by the ease with which it can be acquired." (Pankhurst 1927: 48-49)

12 "Governments desirous of furthering the establishment of a world-auxiliary should first endow interlanguage research. Chairs of synthetic philology should be established in all universities. An Interlanguage Institute should be created for comparative inter-European philological research; for the study of compromise-languages, for the classification and analysis of grammar and phonetics, and for research into their evolution in all parts of the world, viewed from the interlanguage standpoint. This Institute should be established in each country and at an international centre. The greatest philologists should be enlisted for its work. Reports should be issued by it to the Press, the Learned Societies, and educational institutions. Its function would be advisory, but if it were an efficient body, it would achieve a commanding influence." (Pankhurst 1927: 87) 


\section{Bibliography}

Academia pro Interlingua 1931: Key to Interlingua. London: Kegan Paul.

Couturat Louis 1899: Correspondance. Le Temps, 13808 (27/03/1899).

Couturat Louis 1901: La Logique de Leibniz. Paris: Felix Alcan.

Couturat Louis 1906: Pour la Langue Internationale. Coulommiers: Paul Brodard.

Couturat Louis 1911: Des rapports de la Logique et de la Linguistique dans le Problème de la Langue Internationale. Revue de Métaphysique et de Morale, (19 4): 509-516.

Couturat Louis, Jespersen Otto, Lorenz Richard, Ostwald Wilhelm, Pfaundler Leopold 1910: International Language and Science. London: Constable \& co.

Gordon W. Terrence 1990: C. K. Ogden: a bio-bibliographic study. Metuchen, NJ \& London: The Scarecrow Press.

Guérard Albert Léon 1922: A Short History of the International Auxiliary Language Movement. New York: Boni.

Hogben Lancelot 1943: Interglossa. New York : Penguin Books.

Jespersen Otto 1922: Language. Its Nature, Development and Origin. London: Allen \& Unwin.

Kennedy Hubert 1980: Peano. Life and Works of Guiseppe Peano. Dordrecht: Springer.

Ogden Charles Kay 1931: Debabelization: With a Survey of Contemporary Opinion on the Problem of a Universal Language. London: Kegan Paul, Trench, Trubner. Repr. in: Ogden 1994: 227266.

Ogden Charles Kay, Gordon W. Terrence (ed.) 1994: From Bentham to Basic English. London: Routledge: Thoemmes.

Pankhurst Sylvia 1927: Delphos: The Future of International Language. London: Kegan Paul.

Peano Guiseppe 1903: De Latino sine Flexione. Rivista di Matematica 8: 74-83.

Peano Guiseppe 1909: Vocabulario Commune ad Linguas de Europa. Torino: Bocca.

Russell Bertrand 2001: Correspondance sur la philosophie, la logique et la politique avec Louis Couturat 1897-1913. In: Schmid Anne-Françoise (ed.): Paris: Kimé.

Weller Ken 1987: Don't Be A Soldier!: Radical Anti-War Movement in North London, 1914-1918. New York: The Journeyman Press; London: The London History Workshop Centre.

Winslow Barbara 1992: Sylvia Pankhurst and the Great War. In: Block Ian, Pankhurst Richard (eds.): Sylvia Pankhurst. From Artist to Anti-Fascist. London: Palgrave Macmillan.

Zamenhof Ludwik Lejzer 1906: Aspirations of the Founder of Esperanto. Dr. Zamenhof's address to the Second Esperanto Congress. The North American Review 183: 604. 